\title{
Correction: The health services burden of heart failure: an analysis using linked population health data-sets
}

Jane Robertson ${ }^{1,5^{*}}$, Patrick McElduff², Sallie-Anne Pearson ${ }^{3}$, David A Henry ${ }^{1,4}$, Kerry J Inder ${ }^{1}$ and John R Attia ${ }^{1,2}$

\section{Correction}

After publication of this work [1], we noted that we inadvertently included the wrong version of Table two. The Charlson scores presented in the table of the published paper did not exclude heart failure (as described in the methods). Therefore all estimates of comorbidity burden are inflated by one point. While this changes the absolute values of the comorbidity burden it does not alter the conclusions of the study or the patterns of comorbidity described.

The correct data are shown in the following revised Table two (Table 1 here):

The revised text in the results should read:

\section{Comorbidity burden}

Patients had a median of 1.0 comorbidity recorded at baseline admission, although the range was wide $(0-12$, not including heart failure), with some evidence of an increase in comorbidity burden over time Table two (Table 1 here). Re-calculation of the Charlson Index from hospital separation codes at the index admission and all admissions in the previous two years combined did not change the estimates substantially. Across the cohort this had the effect of increasing the mean number of comorbidities per patient by 0.5 , with the median number of recorded comorbidities increasing from 1.0 to 2.0.

\footnotetext{
* Correspondence: jane.robertson@newcastle.edu.au

${ }^{1}$ School of Medicine and Public Health, The University of Newcastle, Newcastle, Australia

${ }^{5}$ Clinical Pharmacology, Calvary Mater Hospital, The University of Newcastle, Clinical Sciences Building, Waratah, NSW 2298, Australia

Full list of author information is available at the end of the article
}

(c) 2013 Robertson et al.; licensee BioMed Central Ltd. This is an Open Access article distributed under the terms of the Creative Commons Attribution License (http://creativecommons.org/licenses/by/2.0), which permits unrestricted use, distribution, and reproduction in any medium, provided the original work is properly cited. 
Table 1 Co-morbidity burden assessed by Charlson Index

\begin{tabular}{|c|c|c|c|c|c|c|}
\hline Variable & Statistic & $\begin{array}{l}2002-03^{*} \\
(\mathrm{~N}=5854)\end{array}$ & $\begin{array}{l}2003-04 \\
(N=5935)\end{array}$ & $\begin{array}{l}2004-05 \\
(N=5606)\end{array}$ & $\begin{array}{l}2005-06 \\
(N=5813)\end{array}$ & $\begin{array}{l}2006-07 \\
(N=5953)\end{array}$ \\
\hline Charlson Score & mean (sd) & $1.2(1.5)$ & $1.2(1.5)$ & $1.5(1.6)$ & $1.3(1.5)$ & $1.4(1.6)$ \\
\hline (based on index admission) & median & 1.0 & 1.0 & 1.0 & 1.0 & 1.0 \\
\hline$(q 1, q 3)$ & $(q 1, q 3)$ & $(0.0,2.0)$ & $(0.0,2.0)$ & $(0.0,2.0)$ & $(0.0,2.0)$ & $(0.0,2.0)$ \\
\hline Charlson Score & mean (sd) & $1.7(1.8)$ & $1.8(1.9)$ & $2.0(2.0)$ & $1.8(1.9)$ & $1.9(2.0)$ \\
\hline (based on two years history) & median & 1.0 & 1.0 & 2.0 & 2.0 & 2.0 \\
\hline$(q 1, q 3)$ & $(q 1, q 3)$ & $(0.0,3.0)$ & $(0.0,3.0)$ & $(0.0,3.0)$ & $(0.0,3.0)$ & $(0.0,3.0)$ \\
\hline
\end{tabular}

* Financial Year (1 July - 30 June).

$+\mathrm{N}=$ number of persons with index admissions.

$\mathrm{sd}=$ standard deviation; q1,q3 = quartile 1, quartile 3 .

\section{Author details}

${ }^{1}$ School of Medicine and Public Health, The University of Newcastle, Newcastle, Australia. ${ }^{2}$ Hunter Medical Research Institute, The University of Newcastle, Newcastle, Australia. ${ }^{3}$ UNSW Cancer Research Centre, University of New South Wales and Prince of Wales Clinical School, Sydney, Australia. ${ }^{4}$ Institute for Clinical Evaluative Sciences and Department of Medicine, University of Toronto, Toronto, Canada. ${ }^{5}$ Clinical Pharmacology, Calvary Mater Hospital, The University of Newcastle, Clinical Sciences Building, Waratah, NSW 2298, Australia.

Received: 11 March 2013 Accepted: 11 March 2013

Published: 17 May 2013

\section{References}

1. Robertson J, McElduff P, Pearson S-A, Henry DA, Inder KJ, Attia JR: The health services burden of heart failure: an analysis using linked population health data-sets. BMC Health Services Research 2012 12:103. doi:10.1186/1472-6963-12-103

\section{Submit your next manuscript to BioMed Central and take full advantage of:}

- Convenient online submission

- Thorough peer review

- No space constraints or color figure charges

- Immediate publication on acceptance

- Inclusion in PubMed, CAS, Scopus and Google Scholar

- Research which is freely available for redistribution 